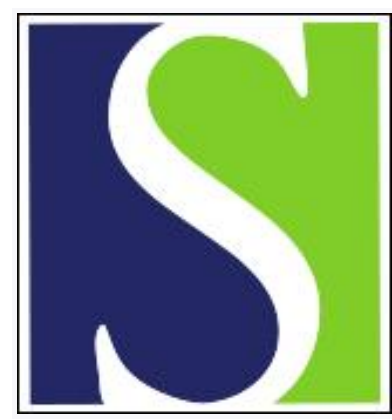

Scand J Work Environ Health 2015;41(6):579-593

https://doi.org/10.5271/sjweh.3523

Issue date: 01 Nov 2015

Dysregulation of markers of oxidative stress and DNA damage among nail technicians despite low exposure to volatile organic compounds

by Grešner P, Stepnik M, Król MB, Swiercz R, Smok-Pieniazek A, Twardowska E, Gromadzińska J, Wasowicz W

This study suggests that the levels of biomarkers of oxidative stress and DNA damage among nail technicians seem to be dysregulated even despite the low level of occupational exposure to volatile organic compounds (VOC). Although the outcomes are not fully conclusive, association of observed changes with occupational exposure to airborne VOC cannot be ruled out.

Affiliation: Department of Toxicology and Carcinogenesis, Nofer Institute of Occupational Medicine, 8, Sw. Teresy St.91-348 Lodz, Poland.pgresner@imp.lodz.pl

Refers to the following text of the Journal: 1998;24(4):270-275

Key terms: biomarker; DNA; DNA damage; dysregulation; exposure; marker of oxidative stress; nail technician; occupational exposure; VOC; volatile organic compound

This article in PubMed: www.ncbi.nlm.nih.gov/pubmed/26348975 


\title{
Dysregulation of markers of oxidative stress and DNA damage among nail technicians despite low exposure to volatile organic compounds
}

\author{
by Peter Grešner, PhD, ${ }^{1}$ Maciej Stępnik, PhD, ${ }^{1}$ Magdalena Beata Król, MSc, ${ }^{1}$ Radosław Świercz, \\ PhD, ${ }^{1}$ Anna Smok-Pieniążek, MSc, ${ }^{1}$ Ewa Twardowska, MSc, ${ }^{1}$ Jolanta Gromadzińska, PhD, ${ }^{1}$ \\ Wojciech Wąsowicz, PhD ${ }^{1}$
}

\begin{abstract}
Grešner P, Stępnik M, Król MB, Świercz R, Smok-Pieniążek A, Twardowska E, Gromadzińska J, Wąsowicz W. Dysregulation of markers of oxidative stress and DNA damage among nail technicians despite low exposure to volatile organic compounds. Scand J Work Environ Health. 2015;41(6):579593. doi:10.5271/sjweh.3523
\end{abstract}

Objective The study aimed to compare levels of selected biomarkers of oxidative stress and DNA damage and their correlation with occupational exposure to volatile organic compounds (VOC) among female nail technicians and a group of unexposed volunteers.

Methods A panel of biomarkers of oxidative stress and DNA damage was assayed among 145 female nail technicians and 152 healthy female volunteers. Occupational exposure of nail technicians to VOC was assessed analyzing the VOC content in nail salon air samples.

Results The level of occupational exposure of nail technicians to VOC was below the respective threshold limit values, with combined airborne exposure to a mixture of VOC reaching only $3.3 \%$ (range $0.2-33.3 \%$ ) of the threshold limit. Despite that, nail technicians presented increased activity of glutathione peroxidase 1 (GPx1), plasma ceruloplasmin, and the GPx1/superoxide dismutase 1 ratio $(\mathrm{P}<0.0001)$. The levels of plasma thiobarbituric acid-reactive species and DNA strand breakage in blood leukocytes were not significantly different. In contrast, total and oxidatively-generated DNA damage were significantly decreased among nail technicians compared to controls $(\mathrm{P}<0.0001)$. The individual's current tobacco smoking and alcohol consumption status did not modulate the observed changes. Significant correlations between selected biomarkers of oxidative stress, DNA damage, and airborne levels of VOC (eg, ethanol) were found.

Conclusions The levels of biomarkers of oxidative stress and DNA damage among nail technicians seem to be dysregulated despite the low level of occupational exposure to VOC. Although the outcomes are not fully conclusive, our findings point to possible causation related to prolonged low-level occupational exposure to VOC.

Key terms biomarker; occupational exposure; VOC.

Due to the increased popularity of nail salon services among women throughout the western world, the number of nail salons and licensed technicians has increased dramatically. For example, the number of nail technicians registered in the US has increased by over $340 \%$ since 1991, reaching almost 400000 in 2005 (1). According to estimates of the Central Statistical Office, in Poland there are currently $>100000$ registered nail technicians (unpublished data).

Nail technicians are occupationally exposed to various cosmetic products which contain a number of poten- tially dangerous chemicals including volatile organic compounds (VOC). Among them, organic solvents such as ethanol, acetone, toluene, and several acetates are the most frequent ones. The International Agency for Research on Cancer (IARC) has classified ethanol as a group 1 carcinogen, and prolonged exposure to this compound has been recognized as a strong risk factor for several forms of cancer. Although the formation of acetaldehyde, a primary metabolite of ethanol, is widely considered as major mechanism underlying the genotoxic and carcinogenic effects of ethanol, other possible

1 Department of Toxicology and Carcinogenesis, Nofer Institute of Occupational Medicine, Lodz, Poland.

Correspondence to: Peter Grešner, PhD, Department of Toxicology and Carcinogenesis, Nofer Institute of Occupational Medicine, 8, Sw. Teresy St.91-348 Lodz, Poland. [E-mail: pgresner@imp.lodz.pl] 
mechanisms - including ethanol-mediated facilitation of the penetration of other carcinogens as well as the induction of oxidative stress - have been proposed (2). The IARC has classified acetone, on the other hand, as a respiratory toxicant but not as a carcinogen. In the case of toluene and xylene, the toxicity of these organic solvents has been studied for decades. Nowadays, the toluene neurotoxicity, ototoxicity, and reproductive toxicity (3-6) - as well as the neurotoxicity and irritatant effects of xylene towards mucous membranes of eyes and upper aerodigestive tract (7-9) - seem all to be considered a fact. Nevertheless, interest in the oxidative damage caused by these solvents' toxic effects have only is relatively new, and thus the amount of evidence concerning their possible genotoxic and carcinogenic potential is scarce and still under discussion. Even though these substances are considered to be neither carcinogenic nor genotoxic to humans (IARC class 3 carcinogens, ie, not classifiable as to their carcinogenicity to humans), there is a growing amount of evidence suggesting increased (i) levels of markers of oxidative stress (10-12), (ii) rate of chromosomal aberrations or sister chromatid exchange (12-14), and (iii) incidence of various cancers among workers occupationally exposed to toluene or xylene [even at occupational exposures far below the respective occupational limits (15-21)]. Although precise mechanisms underlying the effects of toluene and xylene remain unknown, the role of oxidative stress, oxidative DNA damage and dysregulated cellular antioxidant levels have been implicated (22-24). Methacrylates, another group of chemicals used in nail industry, are known sensitizers and were found to give positive results for in vitro genotoxicity, although in vivo outcomes are inconclusive $(25,26)$.

Although nail technicians continue to be in repeated and prolonged contact with many of these substances, the impact on their health and the resultant health hazards related to the nail industry have long been underestimated. This is mainly due to the fact that airborne exposures to these chemicals are lower compared to those found in industry and respective occupational standards. Meanwhile, prolonged exposure and working procedures that bring chemical products in close proximity to the worker's breathing zone and eyes may facilitate the penetration of VOC vapors contained in nail polishes, lacquer removers, or resins into the worker's body.

Recent studies have indeed reported that occupational exposure to chemical products used in the nail industry may be associated with various adverse health effects including skin, eyes, and upper-airways mucosa irritation, headaches, musculoskeletal and reproductive system disorders, and asthma (1, 27-32). Nevertheless, not much is known about how such exposure affects the levels of biochemical markers among nail technicians.
Therefore, the aim of this study was to (i) evaluate the levels of a panel of selected biomarkers of oxidative stress and DNA damage among female nail technicians and (ii) test their differences against healthy unexposed controls. Biomarkers of oxidative stress assayed in this study included the level of blood plasma biomarker of lipid peroxidation (thiobarbituric acid-reactive species; TBARS) and a series of biomarkers of enzymatic antioxidant defense, ie, the blood plasma levels of ceruloplasmin ( $\mathrm{Cp})$, the blood plasma activity of GPx3), the red blood cells' activities of GPx1 and zinc-copper superoxide dismutase (SOD1), as well as the GPx1/ SOD1 ratio as an indicator of altered rate of cellular $\mathrm{H}_{2} \mathrm{O}_{2}$ generation and cellular senescence. Levels of all these biomarkers of oxidative stress and DNA damage among nail technicians were tested for mutual associations as well as for associations with occupational exposure to VOC to assess whether they might be attributable to the occupational exposure of nail technicians.

\section{Methods}

\section{Recruitment of study and control subjects}

The study group consisted of nail salon technicians recruited from nail or beauty salons providing manicure or artificial nail sculpturing services selected randomly within the urban area of the city of Lodz in central Poland, with a focus on inclusion of salons from both downtown and suburban areas of the city. In total, 318 nail/beauty salons were contacted during the recruitment. Ultimately, the study group consisted of 145 female nail technicians of Caucasian descent aged 21-64 years (median age at the time of enrollment was 34 years; interquartile range (IQR): $27-42$ years) from 109 different nail or beauty salons. All enrolled nail technicians were scheduled for blood withdrawal and workroom air sampling.

The control group was drawn from a general population restricted to subjects who agreed to undergo examinations and met the main criteria for inclusion in the control group: (i) not involved in the nail industry, (ii) spend most of the work time in sitting position, similar to nail technicians and (iii) not occupationally exposed to VOC (even in the past). Ultimately, 152 healthy female volunteers, aged 19-59 years (median age at the time of enrolment was 33 years; IQR: $27-42$ years) were involved in the control group, which comprised 107 $(70 \%)$ general office and $45(30 \%)$ academic workers without any occupational contact with organic solvents. All control subjects were also of Caucasian descent and citizens of the Lodz district. 
The possible additional effect of environmental exposure to VOC was not taken into account in any of the groups enrolled in this study. A simple questionnaire was used to check the health status of all subjects enrolled in the study, and if any health-related problems (such as fever or any kind of infections) happened to occur to either nail technicians or control subjects on scheduled days, sampling was rescheduled to ensure all subjects were healthy at the time of measurements. Moreover, the personal questionnaire was used to obtain additional information on two major confounders, smoking habits and alcohol consumption, from each female subject enrolled in the study. Based on gathered information, subjects were classified as non-smokers or current smoker according to the US Centers for Disease Control and Prevention definitions (33). Considering the lifetime of biomarkers analyzed in this study, both former ( $\geq 5$ years since the smoking cessation) and never smokers were classified as non-smokers. Current smokers were further classified based on their current tobacco consumption expressed by means of the packyears (PY, ie, the number of cigarette packs smoked per day $\times$ the number of years lived as a current smoker) as light- or moderate-smokers using the grand median $\mathrm{PY}$ for all current smokers enrolled $(\mathrm{PY}=4$; IQR: $0.80-10)$ as the cut-off point. Ethanol (etOH) ingestion was estimated based on average weekly consumption of alcohol drinks and beverages. A typical amount of 25 $\mathrm{ml}, 12.5 \mathrm{ml}$ and $20 \mathrm{ml}$ etOH was assumed for a bottle of beer, a glass of wine and a drink, respectively. As with tobacco-smoking, all subjects declaring ethanol ingestion were classified as light- or moderate-drinkers using a grand median of weekly ethanol ingestion in all subjects reporting alcohol ingestion $(37.5 \mathrm{ml} / \mathrm{week}$; IQR: $18.75-65.0 \mathrm{ml} /$ week) as the cut-off point. A summary of characteristics of both groups involved in the study is provided in table 1 .

In the group of nail technicians, all sampling and analyses were performed between May 2012 and June 2012 (91 subjects) and between September 2012 and November 2012 (54 subjects). Control subjects were sampled and analyzed between May 2013 and June 2013.

Prior to any further measurements, written and informed consent for participation in this study was obtained from each participant. The Bioethics Committee of the Nofer Institute of Occupational Medicine approved the study (resolution no. 5/2011), which was performed according to the guidelines of the Helsinki Declaration for human research.

\section{Blood withdrawal}

A sample of peripheral blood was collected from each participant involved in the study by venipuncture into tubes containing either EDTA or heparin as anticoagu- lants. Heparinized blood was centrifuged (10 minutes, $\left.1500 \times \mathrm{g}, 4^{\circ} \mathrm{C}\right)$ in order to isolate blood plasma, red blood cells (RBC) and leukocytes-containing buffy coat. Further on, blood plasma was frozen at $-80^{\circ} \mathrm{C}$ and subsequently used to determine the level of TBARS, the activity of GPx3 and plasma level of Cp. In lysed RBC the GPx1 and SOD1 activity assays were performed.

\section{Assays of biomarkers of oxidative stress}

A panel of biomarkers of oxidative stress comprising the blood plasma level of TBARS, the blood plasma level of $\mathrm{Cp}$, the blood plasma activity of GPx3, and the $\mathrm{RBC}$ activities of GPx1 and SOD1 were assayed in each subject enrolled in the study.

The blood plasma level of TBARS was determined using the method previously described by Wasowicz et al, based on the reaction of 2-thiobarbituric acid (TBA) with malondialdehyde, which is a naturally occurring side-product of lipid peroxidation (34). The assay was conducted on a PerkinElmer LS50-B fluorescence spectrometer (PerkinElmer, Shelton, CT, USA) and the concentration of TBARS in blood plasma was expressed in $\mu \mathrm{M}$.

The activity of RBC SOD1 was determined spectrophotometrically according to the method described earlier by Beauchamp \& Fridovich (35). The method consists in SOD1-mediated inhibition of the reduction of nitro blue tetrazolium (NBT) and the enzymatic activity of SOD1 was expressed in units per mg haemoglobin $(\mathrm{U} / \mathrm{mg} \mathrm{Hb})$ with 1 unit corresponding to amount of enzyme that reduces the rate of NBT reduction to $50 \%$ per 1 minute.

The GPx activities in peripheral blood plasma (GPx3) and RBC (GPx1) were determined according to method described by Paglia \& Valentine (36) based on spectrophotometric assessment of the oxidation of NADPH in the presence of exogenous glutathione reductase, NADPH, utilizing tert-butyl hydroperoxide as a substrate. The enzymatic activity was expressed in units per milliliter $(\mathrm{U} / \mathrm{ml})$ and unit per gram of haemoglobin $(\mathrm{U} / \mathrm{g} \mathrm{Hb})$ for plasma and $\mathrm{RBC}$, respectively, with 1 unit equal to $1 \mu$ mol NADPH oxidized per 1 minute.

The oxidase activity of $\mathrm{Cp}$ in blood plasma was determined according to a method described earlier by Sunderman \& Nomoto (37), which consists of Cpmediated oxidation of $p$-phenylenediamine hydrochloride yielding a color product measured spectrophotometrically at $535 \mathrm{~nm}$. The rate of formation of the color product, corrected for nonenzymatic oxidation of $p$-phenylenediamine hydrochloride, is proportional to the blood plasma concentration of $\mathrm{Cp}$, expressed in $\mathrm{g} / \mathrm{l}$.

All assays were optimized and performed using a Thermo Scientific Evolution 3000 UV/VIS spectrophotometer (Thermo Scientific, Waltham, MA, USA). 


\section{DNA damage assays}

DNA damage including the single-strand breaks (SSB) and alkali-labile sites (ALS) was assayed in whole blood using alkaline single-cell gel electrophoresis (SCGE; comet assay) method as described by Singh et al (38) and modified by Mc Kelvey-Martin et al (39). One aliquot of whole blood was mixed with nine aliquots of RPMI-1640 medium containing $10 \%$ fetal calf serum and ten aliquots of $2 \%$ (in PBS) molten agarose type VII (low gelling temperature). The mixture was then spread on a slide (Sigma-Aldrich) earlier covered with agarose type I (low EEO) at 1\% concentration in water and dried. The cells embedded in the agarose gel were lysed in cold lysing solution $(2.5 \mathrm{M} \mathrm{NaCl}, 100 \mathrm{mM} \mathrm{Na} 2$ EDTA, 10 $\mathrm{mM}$ Tris base, $\mathrm{pH} 10$, with $1 \%$ Triton $\mathrm{X}-100$ added just before use) at $4{ }^{\circ} \mathrm{C}$ for $\geq 1$ hour. Subsequently, DNA was unwound in an alkaline electrophoresis buffer $(1 \mathrm{mM}$ $\mathrm{Na}_{2}$ EDTA, $300 \mathrm{mM} \mathrm{NaOH}, \mathrm{pH}>13$ ) for 20 minutes to produce single stranded DNA and to express SSB and ALS and electrophoresed in the same alkaline conditions ( 30 minutes, $25 \mathrm{~V}, 300 \mathrm{~mA}, 0.93 \mathrm{~V} / \mathrm{cm}$ ). The gels were then neutralized by rinsing three times with $0.4 \mathrm{M}$ Tris buffer ( $\mathrm{pH}$ 7.5), and the slides were dried for storage.

In parallel analyses, oxidatively generated damage to DNA bases was additionally identified as formamidopyrimidine glycosylase (FPG)-sensitive sites using modified comet assay as described earlier by Collins et al (40). After lysis, the slides were washed three times with an enzyme buffer $\left(0.1 \mathrm{M} \mathrm{KCl}, 0.5 \mathrm{mM} \mathrm{Na}_{2}\right.$ EDTA, $40 \mathrm{mM}$ HEPES-KOH, $0.2 \mathrm{mg} / \mathrm{ml}$ bovine serum albumin, $\mathrm{pH} 8$ ) and incubated with FPG at $1 \mu \mathrm{g} / \mathrm{ml}$ in this buffer (kept at $-80^{\circ} \mathrm{C}$ ) for 30 minutes at $37^{\circ} \mathrm{C}$. The slides were then electrophoresed and neutralized as described above. Finally, the slides were stained with $5 \mu \mathrm{g} / \mathrm{ml}$ DAPI and 50 cells from each slide were analyzed using an Olympus fluorescence microscope (a BX40 instrument; Olympus, Tokyo, Japan) equipped with an image analysis system (Comet IV, Perceptive Instruments, UK).

For each participant, four slides were prepared simultaneously: two for assessment of DNA strand breakage and the other two, which included also the FPG treatment, for the assessment of total DNA damage (ie, DNA strand breakage and oxidatively generated DNA damage). Respective DNA damage was inferred based on the relative amount of DNA in the comet tail (henceforth referred to as \% DNA) obtained via computer-aided image analysis. Oxidatively generated DNA damage (designated as FPG-SSB) was expressed as the difference between the total DNA damage (designated as FPG) and DNA strand breakage (designated as SSB).

Two scorers performed all assays and were involved in analyses of samples from both the nail technicians and control subjects. Both scorers regularly performed control DNA damage assays utilizing the frozen aliquots from a batch of A549 cells as reference standards during the whole assay period (May 2012-June 2013) in order to ensure that obtained outcomes were consistent. Calculated based on outcomes of these control assays, a value of the coefficient of variation $(\mathrm{CV})<10 \%$ was considered as indicative of good consistency of the comet assay outcomes.

\section{Air sampling and chromatographic determination of airborne VOC}

Workroom air samples were collected in 109 nail salons where the 145 nail technicians were employed using the Sensidyne GilAir-3SC EX Atex air sampling pumps (Sensidyne, Clearwater, FL, USA) equipped with Anasorb 747 sorbent tubes (SKC, Dorset, UK). All measurements were performed as stationary but, in the case of each nail technician, the sampling pump was placed on a working table directly within the nail technician's working field, close to her breathing zone. Therefore, the collected air samples mimicked the air the nail technician was breathing during the treatment. Each air sampling was performed on a weekday during a busy period in which nail treatments were scheduled and lasted from 41 to 234 minutes (median 116 minutes; IQR 89-142 minutes). A single workroom air sample was collected per salon. If more nail technicians from a given nail salon were enrolled in the study, air sampling was scheduled on a day when all of them were at work and performing nail treatments. Prior to each sampling, sampling pumps were calibrated using a soap bubble flow meter and were operated during sampling at flow rate of $100 \mathrm{ml} / \mathrm{min}$. After sampling, the tubes were stored at $-20^{\circ} \mathrm{C}$ prior to desorption and analysis which were performed according to method described previously by Gjolstad et al (41) with minor modifications. Briefly, solvent tubes were desorbed in $1.5 \mathrm{ml}$ of carbon disulfide and N,N-dimethylformamide $(98: 2, \mathrm{v} / \mathrm{v})$ and sonicated for 30 minutes. Airborne VOC were quantified by means of external standard calibration with volumetrically prepared solution in carbon disulfide and dimethylformamide. Sorbent from an unexposed tube was added in order to correct for desorption efficiency. Chromatographic determination of VOC in workroom air samples was performed using Agilent's 6890N gas chromatograph with 5973 Network mass selective detector and HP-5MS capillary column (Model 19091S-433; 30 $\mathrm{m} \times 0.25 \mathrm{~mm} \times 0.25 \mu \mathrm{m}$ was used (Agilent Technologies, Palo Alto, CA, USA). In all analytical measurements, helium was used as carrier gas. The column temperature was initially held at $35^{\circ} \mathrm{C}$ for 3 minutes, raised at $20^{\circ} \mathrm{C} /$ minute to $80{ }^{\circ} \mathrm{C}$ and then held at $80{ }^{\circ} \mathrm{C}$ for 7 minutes and finally raised by $5{ }^{\circ} \mathrm{C} /$ minute up to $150^{\circ} \mathrm{C}$. The total run-time was 26.25 minutes. Mass spectrometer operated in SCAN mode with an associated $\mathrm{m} / \mathrm{z}$ range set from 40-250. Peak integration was based on extracted 
Table 1. Characteristics of the groups of nail technicians and healthy control volunteers involved in the study.

\begin{tabular}{|c|c|c|c|c|c|c|c|c|}
\hline & \multicolumn{4}{|c|}{ Controls ( $N=152)$} & \multicolumn{4}{|c|}{ Nail technicians ( $\mathrm{N}=145)$} \\
\hline & $\mathrm{N}$ & $\%$ & Median & Range & N & $\%$ & Median & Range \\
\hline Age (years) & & & 33 & $19-59$ & & & 34 & $21-64$ \\
\hline Professional experience (years) & & & 6.0 & $1.0-39.0$ & & & 7.0 & $0.1-42.7$ \\
\hline \multicolumn{9}{|l|}{ Nail services/techniques } \\
\hline Traditional manicure & & & & & 59 & 41 & & \\
\hline Nail sculpturing & & & & & 86 & 59 & & \\
\hline \multicolumn{9}{|l|}{ Current tobacco smoking status $a, b$} \\
\hline Non-smokers & 125 & 83 & & & 101 & 72 & & \\
\hline Light current smokers & 10 & 7 & & & 23 & 16 & & \\
\hline Moderate current smokers & 15 & 10 & & & 17 & 12 & & \\
\hline \multicolumn{9}{|l|}{ Alcohol consumption status ${ }^{\mathrm{a}, \mathrm{b}}$} \\
\hline Non-drinkers & 41 & 27 & & & 26 & 18 & & \\
\hline Light drinkers & 62 & 41 & & & 53 & 37 & & \\
\hline Moderate drinkers & 49 & 32 & & & 66 & 45 & & \\
\hline \multicolumn{9}{|l|}{ Current tobacco load (pack-years) } \\
\hline All current smokers " & & & 10.0 & $0.1-25.0$ & & & 3.1 & $0.1-22.5$ \\
\hline Light current smokers & & & 2.5 & $0.1-3.9$ & & & 0.5 & $0.1-4.0$ \\
\hline Moderate current smokers c & & & 15.0 & $5.0-25.0$ & & & 7.5 & $4.9-22.5$ \\
\hline \multicolumn{9}{|l|}{ Ethanol ingestion (ml.week-1) } \\
\hline All drinkers ${ }^{c}$ & & & 32.5 & $1.6-225.0$ & & & 42.5 & $3.1-162.5$ \\
\hline Light drinkers & & & 16.6 & $1.6-36.3$ & & & 20.0 & $3.1-37.5$ \\
\hline Moderate drinkers & & & 62.5 & $37.5-225.0$ & & & 70.0 & $37.5-162.5$ \\
\hline
\end{tabular}

ion and retention times for standard. All chemicals used in chromatographic assays except for ethanol (Witko, Poland), acetone, N,N-dimethylformamide (both from Polish Chemicals, Poland) and carbon disulfide (Analityk, Poland) were from Sigma-Aldrich (USA).

\section{Statistical analysis}

Normal distribution of numerical data was tested by means of the Shapiro-Wilk $W$ test. Data departing from normal distribution are provided as median [range]. Since the majority of experimental numerical data met all relevant criteria for normal distribution but were found to be significantly right-skewed, they were logarithmically transformed (using natural logarithm) prior to any further analyses. Transformed data fulfilling all the criteria for normal distribution are presented as mean with corresponding standard deviation (SD) and expressed in ln units. Analysis of outliers was performed on the basis of estimated Cook's distances. Inter-group comparisons of normally distributed data adjusted for differences in age were performed by means of the analysis of covariance (ANCOVA) employing two different approaches: the analysis either (i) involved each subject's current PY and estimated weekly ethanol ingestion as confounders in order to control for these two additional factors likely affecting the resultant level of oxidative stress and DNA damage, or (ii) was performed following the stratification of all enrolled subjects according to their current smoking (ie, non-smokers, current smokers) and alcohol consumption status (never, light, or moderate drinkers) in order to test the interaction of occupational exposure with current smoking or alcohol consumption status. Further stratification of current smokers based on their current tobacco load (ie, light or moderate smokers) could not be used in this approach, due to constraints imposed by the relatively limited number of current smokers in the group of nail technicians, which - upon combination with the alcohol ingestion-based stratification - resulted in a very small size of compared strata and unbalanced statistical model not allowing the analysis to be performed.

Post-hoc comparisons were performed using the Scheffé test. Simple inter-group comparisons for other non-paired data (such as individuals' age, tobacco smoking, and alcohol consumption) were performed using the Mann-Whitney $U$ test or the two-sided Fisher-FreemanHalton exact test, depending on the character and distribution of data. The Spearman's rank correlation $\left(R_{S}\right)$ was used to identify simple associations. The associations between airborne levels of $\mathrm{VOC}$ and biomarkers of oxidative stress and DNA damage were assessed using regression modelling followed by analysis of partial correlations and expressed by means of semi-partial correlation coefficients $r_{s p}$.

Assessment of the combined exposure to mixture of VOC with similar toxicological effects was performed according to the American Conference of Governmental Industrial Hygienists (ACGIH) formula for evaluation 
of additive effect:

$$
\sum \frac{C}{N}=\frac{C_{1}}{N_{1}}+\frac{C_{2}}{N_{2}}+\ldots+\frac{C_{n}}{N_{n}}
$$

where $C_{i}$ and $N_{i}$ are the measured airborne concentration and threshold limit value (TLV) for $i^{t h}$ component, respectively. If available, Polish TLV were used for the purposes of this study.

All statistical calculations were performed using the Statistica 10 software package (StatSoft, Tulsa, OK, USA).

\section{Results}

\section{Airborne concentrations of VOC}

Airborne concentrations of all analyzed VOC measured in air samples from 109 nail salon workrooms, together with respective TLV obligatory in Poland are presented in table 2. The table shows that almost all VOC analyzed in this study, except for isopropyl acetate, hexamethyldisiloxane, methyl methacrylate (MMA), and ethyl methacrylate (EMA), were present in huge majority of all workroom air samples. Of these, ethanol, 2-propanol, and ethyl acetate were the most abundant. Nevertheless, the median as well as maximum airborne concentrations of any of VOC analyzed in this study did not reach or exceed the respective value of TLV obligatory in Poland. In line with these outcomes, the combined exposure

Table 2. Airborne concentrations of volatile organic compounds in nail salons $(\mathrm{N}=109)$ and combined exposure of nail technicians to volatile organic compounds. [TLV=threshold limit value. $\Sigma(\mathrm{Ci} /$ $\mathrm{Ni})=\mathrm{ACGIH}$ measure of the additive effect of combined exposure of the mixture of VOC.]

\begin{tabular}{|c|c|c|c|c|c|}
\hline \multirow[t]{2}{*}{ Organic solvent } & \multirow[t]{2}{*}{$\begin{array}{c}\text { TLV } \\
\left(\mathrm{mg} / \mathrm{m}^{3}\right)\end{array}$} & \multirow[t]{2}{*}{$\mathrm{N}$} & \multirow[t]{2}{*}{$\%$} & \multicolumn{2}{|c|}{$\begin{array}{c}\text { Airborne level } \\
\left(\mathrm{mg} / \mathrm{m}^{3}\right)\end{array}$} \\
\hline & & & & Median & Range \\
\hline Ethanol & 1900 & 106 & 97 & 3.60 & $0.06-54.77$ \\
\hline Acetone & 600 & 107 & 98 & 0.61 & $0.03-61.69$ \\
\hline Toluene & 100 & 104 & 95 & 0.01 & $0.00-0.62$ \\
\hline 2-propanol & 900 & 107 & 98 & 2.33 & $0.11-37.70$ \\
\hline 2-butanone & 200 & 98 & 90 & 0.05 & $0.00-1.63$ \\
\hline Ethyl acetate & 200 & 106 & 97 & 1.99 & $0.03-44.54$ \\
\hline Isopropyl acetate & 600 & 71 & 65 & 0.01 & $0.00-0.22$ \\
\hline n-butyl acetate & 200 & 106 & 97 & 0.22 & $0.00-18.53$ \\
\hline Hexamethyldisiloxane ${ }^{a}$ & 1350 & 57 & 52 & 0.01 & $0.00-0.61$ \\
\hline Methyl methacrylate & 100 & 20 & 18 & 0.01 & $0.00-26.00$ \\
\hline Ethyl methacrylate $b$ & 235 & 56 & 51 & 0.05 & $0.00-34.99$ \\
\hline Total & & 109 & 100 & 17.08 & $0.57-139.42$ \\
\hline$\Sigma(\mathrm{Ci} / \mathrm{Ni})$ & 1 & & & 0.033 & $0.002-0.333$ \\
\hline
\end{tabular}

a Since no TLV in Poland is available, it was derived from the Occupational Safety and Health Administration (OSHA) permissible exposure level (PEL) of $200 \mathrm{ppm}$ for the purposes of this study.

b Since no TLV in Poland is available, it was derived from OSHA PEL of $50 \mathrm{ppm}$ for the purposes of this study. of nail technicians to VOC in nail salon workrooms estimated using the ACGIH formula for additive effect of toxicants was found to be very low (median value of 0.033; IQR: 0.014-0.081) and did not reach or exceed the respective TLV of the mixture. Maximum combined exposure to the mixture of VOC was found to be 0.333 , ie, three times below the respective TLV of the mixture.

\section{Biomarkers of oxidative stress and DNA damage levels}

First, the levels of investigated biomarkers of oxidative stress (ie, the blood plasma levels of TBARS and Cp, the blood plasma activity of GPx3, the RBC activities of GPx1 and SOD1 and the GPx1/SOD1 activity ratio) and the DNA damage among nail technicians were compared to controls under a setup in which the inter-group differences in current tobacco smoking and alcohol consumption were controlled for by involving current PY and estimated weekly ethanol ingestion in the ANCOVA as confounders. Outcomes of this analysis are summarized in table 3.

Using this approach, nail technicians were revealed to present a significantly increased activity of $\mathrm{RBC}$ GPx1 [3.04 (SD 0.20) versus 2.67 (SD 0.20) $\mathrm{ln}-\mathrm{U} / \mathrm{g}$ $\mathrm{Hb}, \mathrm{P}<0.0001)$, increased ln-ratio of GPx1/SOD1 (-5.75 (SD 0.19) versus -6.09 (SD 0.30), $\mathrm{P}<0.0001$ ) as well as significantly increased blood plasma concentration of $\mathrm{Cp}(-0.54$ (SD 0.22) versus -0.74 (SD 0.27) $\mathrm{ln}-\mathrm{g} / \mathrm{l}$, $\mathrm{P}<0.0001)$ compared to unexposed volunteers. No significant differences between nail technicians and unexposed controls were found for the blood plasma activity of GPx3, the activity of SOD1, and the blood plasma levels of TBARS.

Table 3. The levels of biomarkers of oxidative stress and DNA damage adjusted for age, current tobacco smoking and alcohol consumption. Between-group significance tested for significance using ANCOVA and confirmed by Scheffé post-hoc text. [SD=standard deviation; TBARS= thiobarbituric acid-reactive species; GPX=glutathione peroxidase; SOD1=zinc-copper superoxide dismutase; FPG=total DNA damage; SSB=DNA strand breakage; FPG-SSB = oxidatively generated DNA damage; $\%$ DNA=relative amount of DNA in the comet tail.]

\begin{tabular}{|c|c|c|c|c|}
\hline & \multicolumn{2}{|c|}{$\begin{array}{l}\text { Controls } \\
(\mathrm{N}=152)\end{array}$} & \multicolumn{2}{|c|}{$\begin{array}{l}\text { Nail technicians } \\
\quad(\mathrm{N}=145)\end{array}$} \\
\hline & Mean & SD & Mean & SD \\
\hline TBARS $(\ln -\mu \mathrm{M})$ & 0.48 & 0.25 & 0.53 & 0.25 \\
\hline GPX3 (In-U/ml) & 1.80 & 0.17 & -1.80 & 0.14 \\
\hline GPX1 (In-U/g Hb) a & 2.67 & 0.20 & 3.04 & 0.20 \\
\hline$C p(\ln -g / l)$ a & -0.74 & 0.27 & -0.54 & 0.22 \\
\hline SOD1 (In-U/mg Hb) & 1.86 & 0.21 & 1.88 & 0.12 \\
\hline $\ln (\mathrm{GPX} 1 / \mathrm{SOD} 1)^{\mathrm{a}}$ & -6.09 & 0.30 & -5.75 & 0.19 \\
\hline $\mathrm{FPG}(\operatorname{In}-\% \mathrm{DNA})^{\text {a }}$ & 2.17 & 0.29 & 1.73 & 0.27 \\
\hline SSB (In- $\%$ DNA) & 1.03 & 0.31 & 1.06 & 0.33 \\
\hline FPG-SSB (In-\% DNA) a & 1.70 & 0.52 & 0.84 & 0.68 \\
\hline
\end{tabular}

a $P<0.0001$. 
Concerning the DNA damage, nail technicians presented statistically significant decrease in total amount of DNA damage compared to unexposed volunteers (1.73 (SD 0.27) versus 2.17 (SD 0.29) $1 n-\%$ DNA, $\mathrm{P}<0.0001)$. Similar decrease was observed also in the case of oxidatively-generated DNA damage $(0.84$ (SD 0.68 ) versus 1.70 (SD 0.52) ln- $\%$ DNA, $\mathrm{P}<0.0001$ ), but not in the case of the amount of DNA strand breakage.

Biomarkers of oxidative stress and DNA damage stratified by smoking and alcohol-consumption status

The outcomes of the stratified analysis are summarized in tables $4 \mathrm{a}$ and $4 \mathrm{~b}$.The above described increased activity of RBC GPx1 and plasma levels of Cp among nail tech- nicians were found also in all strata obtained following the stratification by current tobacco smoking and alcohol consumption status $(\mathrm{P}<0.0001$ for the main effect of occupational exposure in the case of both biomarkers).

The increase in GPx1 activity among nail technicians was not found to be modulated by current tobaccosmoking status as both the non- and current smoker strata revealed the similar statistically significant difference $(\mathrm{P}<0.0001$ for both strata; table $4 \mathrm{~A})$. On the other hand, it was found to be further modulated by alcohol-consumption status $(\mathrm{P}<0.005$ for interaction), as the difference in RBC GPx1 activity between nail technicians and controls was slightly attenuated in lightdrinkers (drinkers with weekly ethanol ingestion $<37.5$ $\mathrm{ml} /$ week) compared to never- and moderate-drinkers.

Table 4a. Levels of biomarkers of oxidative stress and DNA damage in healthy control volunteers and nail technicians stratified by current tobacco smoking status. Between-group significance tested for significance using ANCOVA and confirmed by Scheffé post-hoc text. [SD=standard deviation; TBARS=thiobarbituric acid-reactive species; $\mathrm{GPx}=$ glutathione peroxidase; $\mathrm{Cp}=$ ceruloplasmin; $\mathrm{SOD} 1=\mathrm{zinc}$-copper superoxide dismutase; FPG=total DNA damage; SSB=DNA strand breakage; FPG-SSB=0xidatively generated DNA damage; \% DNA=relative amount of DNA in the comet tail.]

\begin{tabular}{|c|c|c|c|c|c|c|c|c|}
\hline & \multicolumn{4}{|c|}{ Current non-smokers } & \multicolumn{4}{|c|}{ Current smokers } \\
\hline & \multicolumn{2}{|c|}{ Controls ( $N=125)$} & \multicolumn{2}{|c|}{ Nail technicians ( $\mathrm{N}=99$ ) } & \multicolumn{2}{|c|}{ Controls $(\mathrm{N}=27)$} & \multicolumn{2}{|c|}{ Nail technicians ( $\mathrm{N}=41)$} \\
\hline & Mean & SD & Mean & SD & Mean & SD & Mean & SD \\
\hline TBARS [In- $\mu \mathrm{M}]$ & 0.45 & 0.24 & 0.53 & 0.25 & 0.57 & 0.29 & 0.52 & 0.25 \\
\hline GPx3 [In-U/ml] & -1.81 & 0.17 & -1.77 & 0.13 & -1.74 & 0.14 & -1.83 & 0.14 \\
\hline GPx1 [In-U/g Hb] & 2.68 & 0.21 & 3.05 & 0.19 a & 2.65 & 0.17 & 3.02 & $0.21^{\mathrm{a}}$ \\
\hline Cp [ln-g/l] & -0.74 & 0.26 & -0.54 & $0.23^{a}$ & -0.73 & 0.29 & -0.54 & $0.20^{\mathrm{b}}$ \\
\hline SOD1 [ln-U/mg Hb] & 1.86 & 0.21 & 1.89 & 0.11 & 1.87 & 0.17 & 1.86 & 0.14 \\
\hline $\ln (\mathrm{GPX} 1 / \mathrm{S} 0 \mathrm{D} 1)$ & -6.09 & 0.31 & -5.74 & $0.19 a$ & -6.12 & 0.23 & -5.75 & $0.19 \mathrm{a}$ \\
\hline FPG [In-\% DNA] & 2.17 & 0.29 & 1.75 & $0.28^{a}$ & 2.09 & 0.32 & 1.68 & 0.24 a \\
\hline SSB [In- $\%$ DNA] & 1.03 & 0.31 & 1.07 & 0.34 & 0.99 & 0.31 & 1.04 & 0.31 \\
\hline FPG-SSB [In-\% DNA] & 1.71 & 0.51 & 0.89 & $0.65^{a}$ & 1.57 & 0.65 & 0.71 & $0.71^{\mathrm{a}}$ \\
\hline
\end{tabular}

a $P<0.0001$ for post-hoc effects.

${ }^{b} \mathrm{P}<0.005$ for post-hoc effects.

Table $\mathbf{4 b}$. Levels of biomarkers of oxidative stress and DNA damage in healthy control volunteers and nail technicians stratified by current alcohol-consumption status. Between-group significance tested for significance using ANCOVA and confirmed by Scheffé post-hoc text. [SD=standard deviation; TBARS=thiobarbituric acid-reactive species; GPX=glutathione peroxidase; $\mathrm{Cp}=$ ceruloplasmin; SOD1=zinccopper superoxide dismutase; FPG=total DNA damage; SSB=DNA strand breakage; FPG-SSB=0xidatively generated DNA damage; \% DNA=relative amount of DNA in the comet tail.]

\begin{tabular}{|c|c|c|c|c|c|c|c|c|c|c|c|c|}
\hline & \multicolumn{4}{|c|}{ Non-drinkers } & \multicolumn{4}{|c|}{ Light drinkers } & \multicolumn{4}{|c|}{ Moderate drinkers } \\
\hline & \multicolumn{2}{|c|}{ Controls $(\mathrm{N}=41)$} & \multicolumn{2}{|c|}{$\begin{array}{l}\text { Nail technicians } \\
(\mathrm{N}=26)\end{array}$} & \multicolumn{2}{|c|}{ Controls $(\mathrm{N}=62)$} & \multicolumn{2}{|c|}{$\begin{array}{l}\text { Nail technicians } \\
\quad(\mathrm{N}=52)\end{array}$} & \multicolumn{2}{|c|}{ Controls $(\mathrm{N}=49)$} & \multicolumn{2}{|c|}{$\begin{array}{l}\text { Nail technicians } \\
(\mathrm{N}=66)\end{array}$} \\
\hline & Mean & SD & Mean & SD & Mean & $\mathrm{SD}$ & Mean & SD & Mean & SD & Mean & SD \\
\hline TBARS $[\mathrm{ln}-\mu \mathrm{M}]$ & 0.42 & 0.24 & 0.51 & 0.21 & 0.48 & 0.27 & 0.56 & 0.25 & 0.52 & 0.22 & 0.50 & 0.26 \\
\hline GPX3 [ln-U/ml] & -1.82 & 0.17 & -1.83 & 0.11 & -1.77 & 0.16 & -1.80 & 0.15 & -1.82 & 0.17 & -1.79 & 0.14 \\
\hline GPx1 [In-U/g Hb] a & 2.61 & 0.20 & 3.06 & $0.19 \mathrm{~b}$ & 2.73 & 0.21 & 3.00 & $0.19 b$ & 2.66 & 0.18 & 3.07 & $0.21^{b}$ \\
\hline$C p[\ln -g / l]$ & -0.76 & 0.24 & -0.45 & $0.24 \mathrm{~b}$ & -0.76 & 0.26 & -0.56 & $0.20^{c}$ & -0.69 & 0.29 & -0.56 & 0.23 \\
\hline SOD1 [In-U/mg Hb] & 1.83 & 0.22 & 1.88 & 0.10 & 1.87 & 0.18 & 1.88 & 0.13 & 1.87 & 0.22 & 1.88 & 0.13 \\
\hline $\ln (\mathrm{GPX} 1 / \mathrm{SOD} 1)$ & -6.12 & 0.33 & -5.73 & $0.19 \mathrm{~b}$ & -6.05 & 0.29 & -5.80 & $0.19 b$ & -6.12 & 0.27 & -5.72 & $0.19 \mathrm{~b}$ \\
\hline FPG $\left[\begin{array}{lll}I n-\% & D N A\end{array}\right]$ & 2.13 & 0.33 & 1.66 & $0.18^{b}$ & 2.15 & 0.26 & 1.78 & $0.26^{b}$ & 2.18 & 0.31 & 1.71 & $0.30^{b}$ \\
\hline SSB $\left[\begin{array}{ll}\ln -\% & \mathrm{DNA}\end{array}\right]$ & 0.95 & 0.34 & 0.96 & 0.33 & 1.09 & 0.31 & 1.15 & 0.29 & 1.00 & 0.28 & 1.02 & 0.35 \\
\hline FPG-SSB $[\ln -\%$ DNA] & 1.67 & 0.62 & 0.82 & $0.51^{\mathrm{b}}$ & 1.63 & 0.55 & 0.84 & $0.74^{b}$ & 1.77 & 0.44 & 0.84 & $0.67^{b}$ \\
\hline
\end{tabular}

a $P<0.005$ for interaction.

${ }^{b} P<0.005$ for post-hoc effects.

c $P<0.0001$ for post-hoc effects. 
Nevertheless, the inter-group differences in the never-, light- and moderate-drinker strata were all statistically significant $(\mathrm{P}<0.0001$ for all three strata).

Considering the blood plasma levels of $\mathrm{Cp}$ stratified by the current smoking status, the above described increased blood plasma levels of $\mathrm{Cp}$ among nail technicians were found among both the non- $(\mathrm{P}<0.0001)$ and current smoker $(\mathrm{P}<0.05)$ strata. Following the stratification by alcohol-consumption status, significantly increased levels of $\mathrm{Cp}$ in blood plasma of nail technicians compared to unexposed controls were found in never- and light-drinkers $(\mathrm{P}<0.0001$ and $\mathrm{P}<0.005$, respectively), but not in the stratum of moderate-drinkers. Despite that, the modulatory effect of interaction between the nail salon-related occupational exposure and the alcohol-consumption status on the level of $\mathrm{Cp}$ was not found to be statistically significant.

No modulatory effects of interaction between occupational exposure and tobacco smoking or alcohol ingestion status on GPx1/SOD1 ratio, total DNA damage, oxidatively-generated DNA damage and DNA strand breakage were found, and the results revealed by the stratification analysis were consistent with those obtained under the setup where effects of tobaccosmoking and alcohol-consumption were controlled for.

\section{Correlations between airborne levels of VOC and bio- markers of oxidative stress and DNA damage}

The correlation matrix between measured airborne levels of VOC and biomarkers of oxidative stress and DNA damage among nail technicians is presented in table 5A. Of the three most abundant VOC, only ethanol airborne levels were found to be significantly correlated with nail technicians' $\mathrm{GPx} 3\left(\mathrm{r}_{\mathrm{SP}}=0.162, \mathrm{P}<0.05\right), \mathrm{GPx} 1\left(\mathrm{r}_{\mathrm{SP}}=0.211\right.$; $\mathrm{P}<0.01)$, the GPx1/SOD1 ratio $\left(\mathrm{r}_{\mathrm{sP}}=0.172 ; \mathrm{P}<0.05\right)$ and the amount of DNA strand breakage $\left(\mathrm{r}_{\mathrm{sP}}=0.287\right.$; $\mathrm{P}<0.001$ ) (figure 1 ). In addition to this, the activity of RBC's SOD1 was significantly correlated with airborne isopropyl acetate $\left(\mathrm{r}_{\mathrm{sP}}=0.234, \mathrm{P}<0.05\right)$ and hexamethyldisiloxane $\left(\mathrm{r}_{\mathrm{SP}}=0.241, \mathrm{P}<0.05\right)$. Unexpectedly, airborne toluene, isopropyl acetate, hexamethyldisiloxane and EMA were significantly but negatively correlated with GPx1/SOD1 ratio, level of $\mathrm{Cp}$ and total DNA damage (see table 5A for details).

In nail technicians, the levels of blood plasma biomarker of lipid peroxidation (TBARS) were positively correlated with the RBCs' activity of GPx $1\left(\mathrm{R}_{\mathrm{S}}=0.228\right.$, $\mathrm{P}<0.005)$, the blood plasma levels of $\mathrm{Cp}\left(\mathrm{R}_{\mathrm{S}}=0.370\right.$, $\mathrm{P}<0.0001)$ and the RBCs' GPx1/SOD1 ratio $\left(\mathrm{R}_{\mathrm{S}}=0.177\right.$, $\mathrm{P}<0.01$ ) (table 5B). Considering the direct link between the biomarkers of oxidative stress and DNA damage, the amount of DNA strand breakage correlated positively with the GPx1/SOD1 ratio $\left(\mathrm{R}_{\mathrm{S}}=0.195, \mathrm{P}<0.01\right)$ and negatively with the RBCs' activity of SOD1 $\left(\mathrm{R}_{\mathrm{S}}=\right.$
$-0.276, \mathrm{P}<0.001)$. Moreover, the amount of total DNA damage correlated negatively with the SOD1 activity $\left(R_{S}=-0.180, P<0.05\right)$. The summary of analysis of all mutual correlations between biomarkers of oxidative stress and DNA damage in nail technicians is presented in table 5B.

\section{Discussion}

In this study, we provide evidence in favor of the hypothesis that nail technicians may be subject to altered levels of biomarkers of oxidative stress and DNA damage despite low levels of occupational exposure to VOC. First of all, it has to be stated that the low levels of occupational exposure to individual VOC found in our study are consistent with previous reports. The VOC most frequently detected in nail salon air samples were acetone, ethanol, toluene, 2-propanol, 2-butanone, ethyl acetate and n-butyl acetate (all of them in $>90 \%$ of all samples), in contrast to EMA and MMA, which were found in only $51 \%$ and $18 \%$ of analyzed air samples, respectively. Similar low frequencies of EMA, MMA or both were reported by the majority of previous studies even though the subjects involved in these studies reported an almost exclusive employment of the EMA/MMA-involving techniques of artificial nail sculpturing during their work time $(31,32,41-43)$. It is thus possible that besides techniques employed, other factors (such as ventilation, EMA/MMA content in used nail products, etc) not involved in any of these studies, may influence the resultant relative airborne levels of EMA or MMA.

The whole pool of airborne VOC in nail salons consisted mainly of ethanol, 2-propanol and ethyl acetate, since the median airborne levels of the rest of monitored chemicals were two to three orders of magnitude lower compared to the median levels of these three most abundant ones. Nevertheless, median airborne levels of all the investigated VOC were far below the TLVs obligatory in Poland and none of the 109 nail salons enrolled in our study was seen to exceed the Polish TLV for any of the measured chemicals. It has to be, however, stated that even though the median and maximum values of total amount of airborne VOC found in our study (17.1 $\mathrm{mg} / \mathrm{m}^{3}$ and $139.4 \mathrm{mg} / \mathrm{m}^{3}$, respectively) were consistent with those reported in a recent study by Goldin et al $\left(11 \mathrm{mg} / \mathrm{m}^{3}\right.$ and $87 \mathrm{mg} / \mathrm{m}^{3}$, respectively) (44), the direct comparison of airborne levels of individual VOC in nail salons among different studies is difficult, mainly due to a huge degree of variability of published data and different measures of centrality used by various authors (arithmetic/geometric means, median) (31, 32, 41-43). Either way, median and maximum airborne levels of acetone, 2-butanone, isopropyl alcohol, hexamethyld- 

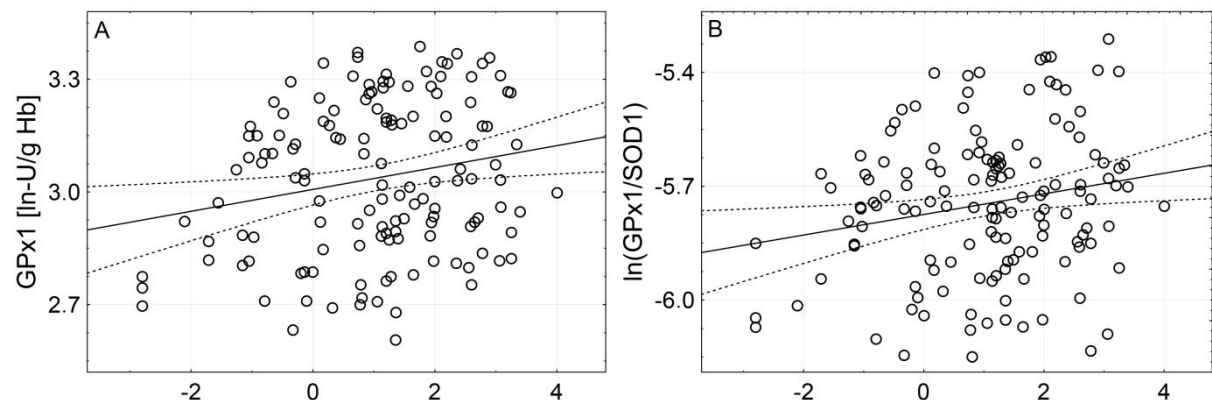

Figure 1. Correlations between airborne level of ethanol and activity of GPX1 (A), In-ratio of GPX1 and SOD1 activities (B), activity of GPX3 (C) and DNA strand breakage (D). Ln-transformed data were used and the levels of significance of associations between biomarkers and airborne ethanol were inferred using regression modelling
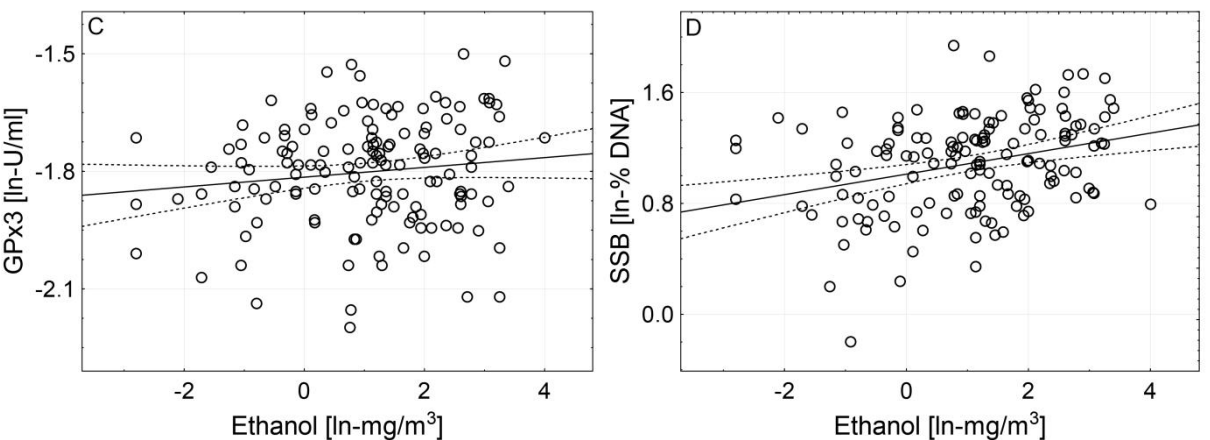
followed by partial correlation analysis. Semi-partial correlation coefficients rsp and levels of significance for individual associations:

$A: r_{s p}=0.212, P<0.01$

B: $r_{\mathrm{sp}}=0.172, P<0.05$

C: $r_{\text {sp }}=0.162, P<0.05$;

$D: r_{s p}=0.287, P<0.001$.

Table 5. Partial correlation analysis. Significant associations are indicated in bold. [TBARS=thiobarbituric acid-reactive species; $\mathrm{GPX}=$ glutathione peroxidase; $\mathrm{C} p=$ ceruloplasmin; SOD1=zinc-copper superoxide dismutase; $\mathrm{FPG}=$ total DNA damage; SSB=DNA strand breakage; FPG-SSB=0xidatively generated DNA damage; EMA=ethyl methacrylate; \% DNA=relative amount of DNA in the comet tail; VOC=volatile organic compound.]

\begin{tabular}{|c|c|c|c|c|c|c|c|c|c|}
\hline & $\begin{array}{l}\text { TBARS } \\
{[\ln -\mu M]}\end{array}$ & $\begin{array}{c}\mathrm{GPX3} \\
{[\mathrm{ln}-\mathrm{U} / \mathrm{ml}]}\end{array}$ & $\begin{array}{c}\mathrm{GPx} 1 \\
{[\mathrm{In}-\mathrm{U} / \mathrm{g} \mathrm{Hb}]}\end{array}$ & $\underset{[\ln -g / l]}{C p}$ & $\begin{array}{c}\text { S0D1 } \\
{[\mathrm{ln}-\mathrm{U} / \mathrm{mg} \mathrm{Hb}]}\end{array}$ & $\begin{array}{c}\ln (\mathrm{GPx} 1 / \\
\text { SOD1) }\end{array}$ & $\begin{array}{c}\mathrm{FPG} \\
{[\ln -\% \text { DNA }]}\end{array}$ & $\begin{array}{c}\text { SSB } \\
{[\mathrm{ln}-\% \text { DNA] }}\end{array}$ & $\begin{array}{c}\text { FPG-SSB } \\
{[\text { In-\%DNA] }}\end{array}$ \\
\hline \multicolumn{10}{|l|}{$A^{a}$} \\
\hline Ethanol [ln-mg/m³] & 0.146 & $0.162^{b}$ & $0.212^{c}$ & 0.112 & 0.080 & $0.172^{b}$ & 0.059 & $0.287^{d}$ & -0.119 \\
\hline Toluene [ln-mg/m³] & 0.021 & -0.089 & -0.068 & -0.103 & 0.159 & $-0.174^{b}$ & -0.118 & -0.119 & -0.028 \\
\hline Isopropyl acetate $\left[\mathrm{ln}-\mathrm{mg} / \mathrm{m}^{3}\right]$ & 0.168 & 0.080 & -0.087 & $-0.237^{b}$ & $0.234^{b}$ & $-0.234 b$ & -0.182 & -0.180 & -0.084 \\
\hline HMDSO [ln-mg/m³] & 0.099 & 0.070 & -0.222 & -0.082 & $0.241^{b}$ & $-0.378 d$ & -0.058 & -0.136 & 0.017 \\
\hline EMA $\left[\mathrm{ln}-\mathrm{mg} / \mathrm{m}^{3}\right]$ & -0.151 & 0.099 & 0.131 & 0.068 & -0.060 & 0.169 & $-0.254^{b}$ & -0.108 & -0.201 \\
\hline \multicolumn{10}{|l|}{$B^{e}$} \\
\hline TBARS [In- $\mu \mathrm{M}]$ & & 0.139 & $0.2288^{f}$ & $0.370^{g}$ & 0.129 & $0.177^{\mathrm{c}}$ & -0.018 & -0.037 & -0.032 \\
\hline GPX3 [In-U/ml] & & & 0.068 & 0.007 & 0.029 & 0.047 & 0.008 & -0.156 & 0.102 \\
\hline GPx1 [ln-U/g Hb] & & & & 0.2949 & $0.373 \mathrm{~g}$ & 0.793 & 0.007 & 0.019 & 0.002 \\
\hline Cp [In-g/l] & & & & & 0.017 & $0.297 \mathrm{~d}$ & 0.059 & 0.005 & 0.064 \\
\hline SOD1 [ln-U/mg Hb] & & & & & & $-0.207^{c}$ & $-0.180^{b}$ & $-0.276 d$ & -0.041 \\
\hline In(GPx1/S0D1) & & & & & & & 0.101 & $0.195^{c}$ & 0.005 \\
\hline FPG $[$ In- $\%$ DNA $]$ & & & & & & & & $0.217^{c}$ & $0.776^{e}$ \\
\hline SSB $[\mathrm{In}-\%$ DNA] & & & & & & & & & $-0.347^{e}$ \\
\hline
\end{tabular}

${ }^{a}$ Semi-partial correlation coefficients ( $\left.r s p\right)$. Values of coefficients were obtained by analyzing the In-transformed data using the forward stepwise regression procedure employing age, current tobacco consumption (in pack-years) and weekly alcohol consumption as confounders. Only those VOC for which at least one significant outcome was found are presented.

e Spearman rank correlation coefficients for mutual correlations between biomarkers of oxidative stress and DNA damage in nail technicians.

b $\mathrm{P}<0.05$

c $P<0.01$.

d $P<0.001$.

${ }^{f} P<0.005$.

g $P<0.0001$. 
isiloxane, and both methacrylates found in our study were substantially lower compared to values published by others. This may in part be explained by the fact that part of nail salons involved in our study did not perform the contemporary nail stylization services employing various VOC but only traditional/biological manicure, in which rather limited number of VOC is used instead. This was not the case in previous studies, all of which were focused on nail salons providing modern nail stylization and sculpturing services only. Furthermore, the air sampling method used, based on short-term stationary measurements, may also have led to slightly under-estimated values. Nevertheless, despite these inconsistencies, our data seem to support the hypothesis that nail salon technicians are rather unlikely being overexposed to airborne $\mathrm{VOC}$, at least in the view of current occupational standards concerning individual VOC. The same seems to hold in the case of combined exposure to a mixture of VOC: since the median and maximum values of additive exposure ( 0.033 and 0.333 , respectively) are both below the threshold value of " 1 ", the occupational overexposure to a mixture of VOC rather cannot be assumed in nail technicians.

Nevertheless, as previous studies reported that even such low but prolonged and repeated occupational exposure may be associated with various adverse health effects observed in nail technicians, we undertook an attempt to investigate the possible effects on the biochemical status of nail technicians. Among nail technicians, significantly increased activities of GPx1 and blood plasma level of $\mathrm{Cp}$, but without any significant changes in the levels of biomarker of blood plasma lipoperoxidation (TBARS) and DNA strand breakage, were found. While interpreting these outcomes, it seems reasonable to assume that increased activities of antioxidant enzymes might be indicative of increased oxidative stress, possibly caused by an occupational exposure of nail technicians. Indeed, exacerbation of oxidative stress has already been implicated in mechanisms underlying the effects exerted by the low-level exposure to VOC in both the animal models $(22,45)$ and human subjects $(10,11,46)$. Notwithstanding, the above-mentioned lack of any significant changes in levels of TBARS and DNA strand breaks between nail technicians and control subjects seems to contradict this thesis. One possible way how to explain this contradiction might be provided by model studies which have raised the notion that if the cellular capacities of antioxidant and DNA damage repair systems are not exceeded, compensatory mechanisms are capable of reducing the transiently increased levels of biomarkers of oxidative stress and DNA damage back to reference control levels. This was reported for both the acute and chronic low-dose exposure to ethanol $(47,48)$. Šarc et al's study (49) showed that low-level of exposure to ethanol may result in increased cellular protein content. Therefore, considering the fact that nail salons provide an environment in which low-level exposure to VOC can be assumed, and the fact that ethanol - the most abundant VOC - was found to correlate positively with biomarkers of oxidative stress (the activities of GPx1 and GPx3, GPx1/SOD1 ratio) and DNA strand breakage, a hypothesis might be drawn that low-level exposure to airborne ethanol might be the key (but not the only) factor responsible for induction of mild oxidative stress among nail technicians, the effects of which (such as DNA damage) might have been, however, successfully compensated for by increased activity of cellular antioxidant enzyme system (indicated by increased activities of antioxidant enzymes). At this stage of our research, this hypothesis, however, remains only a speculation, as no other studies dealing with biochemical status of nail technicians are currently available.

The most unexpected outcome found in our study is undoubtedly the one related to significantly and very distinctly decreased levels of total and oxidativelygenerated DNA damage among nail technicians compared to controls. This finding seems to be in apparent contradiction to those discussed above, as one would expect increased oxidative stress to come hand in hand with increased level of total or oxidatively-generated DNA damage. This was surely not the case in our study. It might be difficult to reasonably explain the decreased levels of total and oxidatively generated DNA damage among nail technicians, but several plausible hypotheses may be proposed. It might be the case that decreased levels of total/oxidatively-generated DNA damage were the result of poorly understood combined action of the mixture of all the airborne VOC or some other effects not involved in our study. Considering the compensatory mechanism suggested above in relation to TBARS and DNA strand breaks, one can also speculate that such distinct decrease in markers of oxidatively-generated and total DNA damage might possibly be attributed to similar, let's say "hormetic" effect, whereby the prolonged low-level exposure of nail technicians to airborne toxicants might have led to mild induction of oxidative stress, subsequent stimulation of enzymatic antioxidant defense, resulting ultimately in decreased levels of total and oxidatively-generated DNA damage. Indeed, two aspects consistent with the basic hormesis concept can be found in our study: (i) the very low level of occupational exposure of nail technicians (median exposure of $3.3 \%$ of the ACGIH threshold for combined exposure), and (ii) the level of reduction of total and oxidativelygenerated DNA damage among nail technicians relative to controls reaching $20 \%$ and $50 \%$, respectively, ie, being within the range of "hormetic stimulation" (50). Moreover, biphasic response to subchronic oxidative stress and the action of VOC has already been reported 
[for reviews see (51-54)]. Therefore, it seems reasonable to state that hormesis cannot be excluded as a possible mechanism underlying the changes in DNA damage observed in our study. On the other hand, the lack of significant correlations between markers of oxidative stress (GPx1 and GPx3 activity, blood plasma levels of TBARS and $\mathrm{Cp}$ ) and biomarkers of DNA damage (either strand, total or oxidatively-generated) in nail technicians fails to provide any direct evidence supportive of this hypothesis. It is thus possible that the coexistence of elevated biomarkers of oxidative stress with decreased total and oxidatively-generated DNA damage among nail technicians may be explained by some other yet unknown mechanism.

In search of a plausible mechanism, the positive correlation between GPx1/SOD1 ratio and the levels of TBARS and DNA strand breakage is intriguing as it might indicate that the DNA damage among nail technicians may not be related to absolute activities of the antioxidant enzymes themselves, but rather to their mutual ratio. A biologically optimal ratio of the activities of the first (SOD) and the second (GPx and catalase) step of enzymatic antioxidant defense has already been shown to exist and deviations from this optimum value were found to lead to altered gene expression, premature senescence, free radical-mediated cell damage, and other cellular perturbations (55-58). It has to be stated that we did not find the GPx1/SOD1 ratio to be significantly correlated with total or oxidatively-generated DNA damage, but only with DNA strand breakage instead. Regretfully, the catalase activity comprising a significant part of the enzymatic antioxidant defense was not assayed in our study, and consequently we are certainly missing some information which might be crucial in order to fully elucidate the mechanism responsible for decreased total and oxidatively-generated DNA damage under discussion. Either way, although it seems reasonable to state that nail technicians present an imbalanced antioxidant enzyme activities together with altered levels of markers of DNA damage, our experimental setup (the lack of dose- or time-response experiments) does not allow us to understand fully the exact mechanism underlying the observed changes.

Notwithstanding, reviewing the data provided in table 3 , it seems reasonable to assume that the decrease in total DNA damage was predominantly caused by the decrease in oxidatively generated DNA damage. Although the above-proposed mechanism based on activation of cellular antioxidant enzyme system cannot be ruled out, other plausible mechanisms are worth mentioning. Obtained outcomes might be, for example, explained by the limited DNA migration in electrophoresis and decreased Comet assay outcomes due to formation of DNA cross-links (59) resulting from occupational exposure of nail technicians to DNA cross-linking agents, such as aldehydes.
Formaldehyde is frequently used in nail products used to make nails stronger (60). Ethanol, the most abundant airborne VOC found in our analyses - once ingested, inhaled, or absorbed - is metabolized into acetaldehyde, another recognized DNA cross-linker (61). DNA crosslinking properties were also reported for endogenous malondialdehyde, a product of lipid peroxidation (62). Therefore, one cannot exclude the possibility that the decreased total and oxidatively generated DNA damage found among nail technicians might be a consequence of technicians' occupational exposure to chemicals causing mainly DNA cross-links, ie, the kind of DNA damage which was poorly detected during our analyses. On the other hand, the occupational exposure to airborne formaldehyde among nail technicians was found to be low previously (63) and the level of airborne ethanol found in our study was several orders of magnitude lower compared to levels at which the DNA cross-linking properties of acetaldehyde were reported. Moreover, the available weight of evidence of genotoxic effects of acetaldehyde formed from airborne ethanol (IARC class 2B carcinogen) is not as convincing as in the case of acetaldehyde formed from ethanol ingested in alcoholic beverages (IARC class 1 carcinogen). Nevertheless, since we did not directly measure the airborne levels of aldehydes in nail salon workrooms in this study, this hypothesis cannot be ruled out and needs to be taken into account. It is also possible that the inter-group differences observed in our study may be at least partly explained by differences in lifestyle and dietary factors which were not considered in this study [ie, moderate physical activity or the coffee intake, both of which can decrease the DNA damage (64, $65)$, or the length of the occupational exposure period]. It is of note that recently a decreased cancer incidence among nail technicians, compared to the general population, was reported (66), an intriguing finding especially in connection with the decreased levels of total/oxidativelygenerated DNA damage reported by the present study. Either way, further research must be warranted in order to provide more insight into this topic.

While interpreting the obtained outcomes considering the possible effect of airborne VOC (or more interestingly the effects of airborne ethanol, the most abundant VOC) on biomarkers of oxidative stress and DNA damage, several limitations have to be taken into account. First, only the induction of oxidative stress due to occupational exposure to VOC was considered in our study, and other genotoxic mechanisms, including the above discussed acetaldehyde-mediated one, were not considered. Second, only static and short-term breathing-zone area measurements were employed in our study, thus the occupational exposure of nail technicians might have been slightly underestimated. Third, a bias might have been introduced into measured levels of biomarkers due to nail technicians and control subjects 
not being sampled in the same year. Fourth, the comet assay might have been ineffective in showing the genotoxic effect of tobacco smoking, thus it might have also been insensitive to other types of DNA damage possibly caused by genotoxic substances to which nail technicians are occupationally exposed. Moreover, the comet assay involving FPG is known to be specific to only one subgroup of oxidative DNA damage, while the basic comet assay can identify certain oxidative DNA damage, as well. Finally, even though the inter-group differences in current tobacco load (in terms of PY smoked) were controlled for in the first part of analysis described in this study, such differences might possibly generate concerns while interpreting our outcomes. Therefore, the controls' and technicians' current tobacco loads were matched with each other using an age-stratified randomization approach. Statistical analysis performed upon such matched groups gave positive verification of all the above described outcomes (data not shown). This indicates that the observed alterations of biomarkers of oxidative stress and DNA damage found among nail technicians cannot be explained by the betweengroup differences in the current tobacco smoking (also suggested by the lack of interaction between current tobacco smoking and occupational exposure). The same seems to be true in the case of alcohol consumption, in the case of which, however, one has to remember that self-reported information on alcohol consumption was used in this study.

\section{Concluding remarks}

To sum up, despite low airborne levels of VOC in nail salon workrooms, we provide evidence of dysregulation of biomarkers of oxidative stress and DNA damage among nail technicians. Even though it might be difficult to determine the precise mechanism underlying these changes in full at this stage of research, it cannot be excluded that they might have occurred due to a prolonged low-level occupational exposure to VOC or other chemicals present in nail salon workrooms. Such alterations were shown to be directly associated with the development of serious disturbances in physiological functions and may possibly lead to pathologies (67). Our study therefore adds to the ever-growing evidence of workplace-related adverse health effects observed among nail technicians. Therefore, as suggested recently by Roelofs \& Do (68), it may be worth reconsidering whether the current exposure assessment approach based on chemical-by-chemical industrial hygiene monitoring is appropriate for this occupational group (which is rarely "overexposed" in the light of the current exposure level standards), and whether it wouldn't be more useful to use the indoor air exposure assessment strategy instead.

\section{Acknowledgements}

The National Science Centre (grant No. PB/2011/01/B/ NZ7/04681) and the Nofer Institute of Occupational Medicine (fund no. IMP 1.18/2013) supported this study.

The authors declare no conflicts of interest.

\section{References}

1. Roelofs C, Azaroff LS, Holcroft C, Nguyen H, Doan T. Results from a community-based occupational health survey of Vietnamese-American nail salon workers. J Immigr Minor Health. 2008;10(4):353-61. http://dx.doi.org/10.1007/ s10903-007-9084-4.

2. Yu HS, Oyama T, Isse T, Kitagawa K, Pham TT, Tanaka M, et al. Formation of acetaldehyde-derived DNA adducts due to alcohol exposure. Chem Biol Interact. 2010;188(3):367-75. http://dx.doi.org/10.1016/j.cbi.2010.08.005.

3. International Agency for Research on Cancer (IARC). Toluene. In: Reevaluation of some organic chemicals, hydrazine and hydrogen peroxide. Lyon: IARC; 1999. IARC monographs on the evaluation of the carcinogenic risks of chemicals to humans, vol. 71. p. 829-64.

4. U.S. Environemental Protection Agency (EPA). Toxicological Review of Toluene. In support of summary information on the integrated risk information system (IRIS). Washington; 2005.

5. Greenberg MM. The central nervous system and exposure to toluene: a risk characterization. Environ Res. 1997;72(1):1-7. http://dx.doi.org/10.1006/enrs.1996.3686.

6. Jakubowski M. Toluene. [Toluen. Dokumentacja dopuszczalnych wielkości narażenia zawodowego]. PiMOSP 2007;3(53):131-58.

7. Ligocka D. Xylene (all isomers). [Ksylen - mieszanina izomerów. Dokumentacja dopuszczalnych wielkości narażenia zawodowego]. PiMOSP 2007;4(54):139-65

8. International Agency for Research (IARC). Xylene. In: Reevaluation of some organic chemicals, hydrazine and hydrogen peroxide. Lyon: IARC; 1999. IARC monographs on the evaluation of the carcinogenic risks of chemicals to humans, vol. 71. p. 1189-208.

9. U.S. Environemental Protection Agency (EPA). Toxicological review of xylenes. In support of summary information on the integrated risk information system (IRIS). Washington; 2003.

10. Kim JH, Moon JY, Park EY, Lee KH, Hong YC. Changes in oxidative stress biomarker and gene expression levels in workers exposed to volatile organic compounds. Ind Health. 2011;49(1):8-14. http://dx.doi.org/10.2486/indhealth. MS1112.

11. Moro AM, Charão M, Brucker N, Bulcão R, Freitas F, Guerreiro G, et al. Effects of low-level exposure to xenobiotics present in paints on oxidative stress in workers. Sci Total Environ. 2010;408(20):4461-7. http://dx.doi.org/10.1016/j. 
scitotenv.2010.06.058

12. Manikantan P, Balachanadar V, Sasikala K, Mohanadevi S, Arun M, Kumar AK, et al. Cytogenetic methods for assessing human exposure to toluene in Coimbatore, South India. Asian Pac J Cancer Prev. 2010;11(6):1687-93.

13. Tunca BT, Egeli U. Cytogenetic findings on shoe workers exposed long-term to benzene. Environ Health Perspect. 1996;104 Suppl:1313-7. http://dx.doi.org/10.1289/ ehp.961041313.

14. Bogadi-Sare A, Brumen V, Turk R, Karacic V, Zavalic M. Genotoxic effects in workers exposed to benzene: with special reference to exposure biomarkers and confounding factors. Ind Health. 1997;35(3):367-73. http://dx.doi.org/10.2486/ indhealth.35.367.

15. Gerin M, Siemiatycki J, Desy M, Krewski D. Associations between several sites of cancer and occupational exposure to benzene, toluene, xylene, and styrene: results of a case-control study in Montreal. Am J Ind Med. 1998;34(2):144-56. http://dx.doi.org/10.1002/(SICI)10970274(199808)34:2<144::AID-AJIM7>3.0.CO;2-X.

16. Lundberg I, Milatou-Smith R. Mortality and cancer incidence among Swedish paint industry workers with long-term exposure to organic solvents. Scand J Work Environ Health 1998;24(4):270-5. http://dx.doi.org/10.5271/sjweh.320.

17. Aksoy H, Yilmaz S, Celik M, Yüzbaşioglu D, Unal F. Genotoxicity study in lymphocytes of offset printing workers. J Appl Toxicol. 2006;26(1):10-5. http://dx.doi.org/10.1002/ jat.1098.

18. Svensson BG, Nise G, Englander V, Attewell R, Skerfving $\mathrm{S}$, Möller T. Deaths and tumours among rotogravure printers exposed to toluene. Br J Ind Med. 1990;47(6):372-9. http:// dx.doi.org/10.1136/oem.47.6.372.

19. Leon DA, Thomas P, Hutchings S. Lung cancer among newspaper printers exposed to ink mist: a study of trade union members in Manchester, England. Occup Environ Med. 1994;51(2):87-94. http://dx.doi.org/10.1136/oem.51.2.87.

20. Pitarque M, Vaglenov A, Nosko M, Pavlova S, Petkova V, Hirvonen A, et al. Sister chromatid exchanges and micronuclei in peripheral lymphocytes of shoe factory workers exposed to solvents. Environ Health Perspect. 2002;110(4):399-404. http://dx.doi.org/10.1289/ehp.02110399.

21. Heuser VD, Erdtmann B, Kvitko K, Rohr P, da Silva J. Evaluation of genetic damage in Brazilian footwear-workers: biomarkers of exposure, effect, and susceptibility. Toxicology. 2007 Apr 11;232(3):235-47. http://dx.doi.org/10.1016/j. tox.2007.01.011.

22. Liu Y, Zhou Q, Xie X, Lin D, Dong L. Oxidative stress and DNA damage in the earthworm Eisenia fetida induced by toluene, ethylbenzene and xylene. Ecotoxicology. 2010;19(8):1551-9. http://dx.doi.org/10.1007/s10646-0100540-x.

23. Singh MP, Mishra M, Sharma a, Shukla a K, Mudiam MKR, Patel DK, et al. Genotoxicity and apoptosis in Drosophila melanogaster exposed to benzene, toluene and xylene: attenuation by quercetin and curcumin. Toxicol Appl Pharmacol. 2011;253(1):14-30. http://dx.doi.org/10.1016/j. taap.2011.03.006.

24. Coskun O, Oter S, Korkmaz A, Armutcu F, Kanter M. The oxidative and morphological effects of high concentration chronic toluene exposure on rat sciatic nerves. Neurochem Res. 2005;30(1):33-8. http://dx.doi.org/10.1007/s11064004-9683-6.

25. Johannsen FR, Vogt B, Waite M, Deskin R. Mutagenicity assessment of acrylate and methacrylate compounds and implications for regulatory toxicology requirements. Regul Toxicol Pharmacol. 2008;50(3):322-35. http://dx.doi. org/10.1016/j.yrtph.2008.01.009.

26. Greim H, Ahlers J, Bias R, Broecker B, Hollander H, Gelbke HP, et al. Assessment of structurally related chemicals: toxicity and ecotoxicity of acrylic acid and acrylic acid alkyl esters (acrylates), methacrylic acid and methacrylic acid alkyl esters (methacrylates). Chemosphere. 1995;31(2):2637-59. http:// dx.doi.org/10.1016/0045-6535(95)00136-V.

27. Lazarov A. Sensitization to acrylates is a common adverse reaction to artificial fingernails. J Eur Acad Dermatol Venereol. 2007;21(2):169-74. http://dx.doi.org/10.1111/j.14683083.2006.01883.x.

28. Quach T, Nguyen KD, Doan-Billings PA, Okahara L, Fan C, Reynolds P. A preliminary survey of Vietnamese nail salon workers in Alameda County, California. J Community Health. 2008;33(5):336-43. http://dx.doi.org/10.1007/s10900-0089107-7.

29. Reutman SR, Rohs AM, Clark JC, Johnson BC, Sammons DL, Toennis CA, et al. A pilot respiratory health assessment of nail technicians: symptoms, lung function, and airway inflammation. 2009;52(11):868-75.

30. Harris-Roberts J, Bowen J, Sumner J, Stocks-Greaves M, Bradshaw L, Fishwick D, et al. Work-related symptoms in nail salon technicians. Occup Med (Lond). 2011;61(5):335-40. http://dx.doi.org/10.1093/occmed/kqr096.

31. Quach T, Gunier R, Tran A, Von Behren J, Doan-Billings $\mathrm{PA}$, Nguyen KD, et al. Characterizing workplace exposures in Vietnamese women working in California nail salons. Am J Public Health. 2011;101 Suppl 1:S271-6. http://dx.doi. org/10.2105/AJPH.2010.300099.

32. Park SA, Gwak S, Choi S. Assessment of occupational symptoms and chemical exposures for nail salon technicians in daegu city, Korea. J Prev Med Public Health. 2014;47(3):16976. http://dx.doi.org/10.3961/jpmph.2014.47.3.169.

33. Schoenborn CA, Adams PF. Health behaviors of adults: United States, 2005-2007. National Center for Health Statistics. Vital Health Stat. 2010;10(245):80.

34. Wasowicz W, Neve J, Peretz A. Optimized steps in fluorometric determination of thiobarbituric acid-reactive substances in serum: importance of extraction $\mathrm{pH}$ and influence of sample preservation and storage. Clin Chem. 1993;39(12):2522-6.

35. Beauchamp C, Fridovich I. Superoxide dismutase: improved assays and an assay applicable to acrylamide gels. Anal Biochem. 1971;44(1):276-87. http://dx.doi. org/10.1016/0003-2697(71)90370-8.

36. Paglia DE, Valentine WN. Studies on the quantitative and 
qualitative characterization of erythrocyte glutathione peroxidase. J Lab Clin Med. 1967;70(1):158-69.

37. Sunderman Jr. FW, Nomoto S. Measurement of human serum ceruloplasmin by its p-phenylenediamine oxidase activity. Clin Chem. 1970;16(11):903-10.

38. Singh NP, McCoy MT, Tice RR, Schneider EL. A simple technique for quantitation of low levels of DNA damage in individual cells. Exp Cell Res. 1988;175(1):184-91. http:// dx.doi.org/10.1016/0014-4827(88)90265-0.

39. McKelvey-Martin VJ, Green MH, Schmezer P, PoolZobel BL, De Meo MP, Collins A. The single cell gel electrophoresis assay (comet assay): a European review. Mutat Res. 1993;288(1):47-63. http://dx.doi.org/10.1016/00275107(93)90207-V.

40. Collins AR, Duthie SJ, Dobson VL. Direct enzymic detection of endogenous oxidative base damage in human lymphocyte DNA. Carcinogenesis. 1993;14(9):1733-5. http://dx.doi. org/10.1093/carcin/14.9.1733.

41. Gjolstad M, Thorud S, Molander P. Occupational exposure to airborne solvents during nail sculpturing. J Environ Monit. 2006;8(5):537-42. http://dx.doi.org/10.1039/b601917j.

42. Yang JH, Han D-H. Occupational exposure of nail technicians to airborne chemicals and biological monitoring. J Korean Soc Occup Environ Hyg. 2010;20(1):53-62.

43. Alaves VM, Sleeth DK, Thiese MS, Larson RR. Characterization of indoor air contaminants in a randomly selected set of commercial nail salons in Salt Lake County, Utah, USA. Int J Environ Health Res. 2013;23(5):419-33. http://dx.doi.org/10.1080/09603123.2012.755152.

44. Goldin LJ, Ansher L, Berlin A, Cheng J, Kanopkin D, Khazan $A$, et al. Indoor air quality survey of nail salons in Boston. J Immigr Minor Health. 2014;16(3):508-14. http://dx.doi. org/10.1007/s10903-013-9856-y.

45. Wang F, Li C, Liu W, Jin Y, Guo L. Effects of subchronic exposure to low-dose volatile organic compounds on lung inflammation in mice. Environ Toxicol. 2014;29(9):1089-97. http://dx.doi.org/10.1002/tox.21844.

46. Yoon HI, Hong Y-C, Cho SH, Kim H, Kim YH, Sohn JR, et al. Exposure to volatile organic compounds and loss of pulmonary function in the elderly. Eur Respir J. 2010;36(6):1270-6. http://dx.doi.org/10.1183/09031936.00153509.

47. Navasumrit P, Ward TH, Dodd NJ, O'Connor PJ. Ethanolinduced free radicals and hepatic DNA strand breaks are prevented in vivo by antioxidants: effects of acute and chronic ethanol exposure. Carcinogenesis. 2000;21(1):93-9. http:// dx.doi.org/10.1093/carcin/21.1.93.

48. Lamarche F, Gonthier B, Signorini N, Eysseric H, Barret L. Acute exposure of cultured neurones to ethanol results in reversible DNA single-strand breaks; whereas chronic exposure causes loss of cell viability. Alcohol Alcohol. 2003;38(6):550-8. http://dx.doi.org/10.1093/alcalc/agg118.

49. Sarc L, Lipnik-Stangelj M. Comparison of ethanol and acetaldehyde toxicity in rat astrocytes in primary culture. Arh Hig Rada Toksikol. 2009;60(3):297-305. http://dx.doi. org/10.2478/10004-1254-60-2009-1927.
50. Calabrese EJ. Hormesis is central to toxicology, pharmacology and risk assessment. Hum Exp Toxicol. 2010;29(4):249-61. http://dx.doi.org/10.1177/0960327109363973.

51. Luna-López A, González-Puertos VY, López-Diazguerrero NE, Königsberg M. New considerations on hormetic response against oxidative stress. J Cell Commun Signal. 2014;8(4):323-31. http://dx.doi.org/10.1007/s12079-014$0248-4$

52. Pickering AM, Vojtovich L, Tower J, A Davies KJ. Oxidative stress adaptation with acute, chronic, and repeated stress. Free Radic Biol Med. 2013;55:109-18. http://dx.doi. org/10.1016/j.freeradbiomed.2012.11.001.

53. Calabrese EJ, Baldwin LA. Ethanol and hormesis. Crit Rev Toxicol. 2003;33(3-4):407-24. http://dx.doi. org/10.1080/713611043.

54. CalabreseEJ.U-shaped doseresponse in behavioral pharmacology: historical foundations. Crit Rev Toxicol. 2008;38(7):591-8. http://dx.doi.org/10.1080/10408440802026307.

55. Cristiano F, de Haan JB, Iannello RC, Kola I. Changes in the levels of enzymes which modulate the antioxidant balance occur during aging and correlate with cellular damage. Mech Ageing Dev. 1995;80(2):93-105. http://dx.doi. org/10.1016/0047-6374(94)01561-Y.

56. De Haan JB, Cristiano F, Iannello RC, Kola I. Cu/Znsuperoxide dismutase and glutathione peroxidase during aging. Biochem. Mol Biol Int. 1995;35(6):1281-97.

57. De Haan JB, Cristiano F, Iannello R, Bladier C, Kelner MJ, Kola I. Elevation in the ratio of $\mathrm{Cu} / \mathrm{Zn}$-superoxide dismutase to glutathione peroxidase activity induces features of cellular senescence and this effect is mediated by hydrogen peroxide. Hum Mol Genet. 1996;5(2):283-92. http://dx.doi. org/10.1093/hmg/5.2.283.

58. Groner Y, Elroy-Stein O, Avraham KB, Yarom R, Schickler $\mathrm{M}$, Knobler $\mathrm{H}$, et al. Down syndrome clinical symptoms are manifested in transfected cells and transgenic mice overexpressing the human $\mathrm{Cu} / \mathrm{Zn}$-superoxide dismutase gene. J Physiol (Paris). 1990;84(1):53-77.

59. Miyamae Y, Iwasaki K, Kinae N, Tsuda S, Murakami M, Tanaka M, et al. Detection of DNA lesions induced by chemical mutagens using the single-cell gel electrophoresis (comet) assay. 2. Relationship between DNA migration and alkaline condition. Mutat Res. 1997;393(1-2):107-13. http:// dx.doi.org/10.1016/S1383-5718(97)00091-0.

60. Kieć-Świerczyńska M, Świerczyńska-Machura D. Manikiurzystki i pedikiurzystki jako grupa zawodowa. Medycyna Pracy. 2014;64(4):579-91.

61. Kotova N, Vare D, Schultz N, Gradecka Meesters D, Stepnik $\mathrm{M}$, Grawé J, et al. Genotoxicity of alcohol is linked to DNA replication-associated damage and homologous recombination repair. Carcinogenesis. 2013;34(2):325-30. http://dx.doi. org/10.1093/carcin/bgs340.

62. Niedernhofer LJ, Daniels JS, Rouzer C a., Greene RE, Marnett LJ. Malondialdehyde, a product of lipid peroxidation, is mutagenic in human cells. J Biol Chem. 2003;278(33):3142633. http://dx.doi.org/10.1074/jbc.M212549200. 
63. McNary JE, Jackson EM. Inhalation exposure to formaldehyde and toluene in the same occupational and consumer setting. Inhal Toxicol. 2007;19(6-7):573-6. http://dx.doi. org/10.1080/08958370701270946.

64. Di Pietro A, Visalli G, La Maestra S, Micale R, Baluce B, Matarese G, et al. Biomonitoring of DNA damage in peripheral blood lymphocytes of subjects with dental restorative fillings. Mutat Res. 2008;650(2):115-22. http://dx.doi.org/10.1016/j. mrgentox.2007.10.023.

65. Bakuradze T, Lang R, Hofmann T, Eisenbrand G, Schipp D, Galan J, et al. Consumption of a dark roast coffee decreases the level of spontaneous DNA strand breaks: a randomized controlled trial. Eur J Nutr. 2015;54(1):149-56. http://dx.doi. org/10.1007/s00394-014-0696-x.
66. Quach T, Doan-Billing PA, Layefsky M, Nelson D, Nguyen KD, Okahara L, et al. Cancer incidence in female cosmetologists and manicurists in California, 1988-2005. Am J Epidemiol. 2010;172(6):691-9. http://dx.doi.org/10.1093/ aje/kwq190.

67. Schieber M, Chandel NS. ROS function in redox signaling and oxidative stress. Curr Biol. 2014;24(10):R453-62. http:// dx.doi.org/10.1016/j.cub.2014.03.034.

68. Roelofs C, Do T. Exposure assessment in nail salons: an indoor air approach. ISRN Public Health. 2012;2012:1-7. http:// dx.doi.org/10.5402/2012/962014.

Received for publication: 17 March 2015 